\title{
SYNCHRONIZATION OF ECONOMIC CYCLES IN COUNTRIES OF THE VISEGRAD GROUP, GERMANY AND EUROZONE
}

\author{
Václav Adamec ${ }^{1}$ \\ ${ }^{1}$ Department of Statistics and Operations Research, School of Business and Economics, Mendel University in \\ Brno, Zemědělská 1, 61300 Brno, Czech Republic
}

\begin{abstract}
ADAMEC VÁCLAV. 2018. Synchronization of Economic Cycles in Countries of the Visegrad Group, Germany and Eurozone. Acta Universitatis Agriculturae et Silviculturae Mendelianae Brunensis, 66(3): 719-728.

Most countries of the Visegrad group presently undertake meticulous preparation for entry to the Eurozone, which makes the issue of business cycle synchronization contemporary. In this study, we identified business cycle in V4 member states, Germany and the Eurozone and investigated the degree of business cycle synchronization among V4 countries, with Germany and the Eurozone. Quarterly GDP data, season and calendar adjusted from 1995: 1 through 2016:4 $(T=88)$ were broken down to trend and cyclical elements by the Hodrick-Prescott filter and used to obtain the relative output gap. Phases of the business cycle were identified through modified BBQ algorithm. Business cycle synchronization was quantified with Pearson correlation coefficient, concordance index and Mink similarity index calculated separately for time segments before EU accession in 2004 and after. Tests of statistical significance were carried out, where relevant. In the period before EU enlargement, few economic cycles were correlated weakly, but many were not synchronized at all or were even negatively correlated. After EU accession, the cycles became closely synchronized among V4 countries or between V4 state and Germany or Eurozone. Although the degree of correlation between V4 countries and Eurozone is not as strong, as for Germany and Eurozone, it is obvious that $\mathrm{V} 4$ countries are becoming increasingly prepared for adopting Euro, as their currency, with respect to the requisite of economic cycle synchronization.
\end{abstract}

Keywords: business cycle, HP filter, output gap, correlation coefficient, concordance index, similarity index, synchronization, $R$-software

\section{INTRODUCTION}

Economies of the old and new member states of the EU presently exhibit a series of recurring fluctuations in real GDP around trajectory of its long-term trend that is affecting all areas of the economy, although with unequal extent. The moves in the aggregate domestic product are often tied to cyclical changes in levels of employment, inflation, private consumption, investment and consumer confidence with inevitable and lasting impact upon the fiscal balance of the public budget. Lacina et al. (2007) mentions impact of the economic cycle upon the consumption of the imported products and services followed by changes in the economic policy. Two distinct phases of the business cycle can be recognized: expansions meaning growth of the real output above its trend, positive output gap and high utilization of production factors, and recessions implying total real product shrinkage, negative output gap and release of the vacant resources to the supply side of the economy. Height of both extreme points however depends upon the changing growth trend, which represents the potential product of the economy at full utilization of production factors (Dornbusch et al., 2011). Since, the business cycle is delimited by two consecutive peaks, correct identification of the extreme points and phases of the cycle therefore becomes an important task for the economic analyst. 
Multiple underlying reasons for (un)synchronicity of the economic cycles in two countries were previously reported in the economic literature. They embrace geographic distance: cycles of distant countries tend to become less correlated than those of neighboring countries; similar structure of the economies: primarily elevated share of sectors dependent upon cyclical demand, for example industry, construction sector or tourism; degree of economy openness: open economies usually have greater similarity in cycles, size of the economies: smaller economies tend to adjust movements of economic cycle to large economies and membership in the same monetary union: member states tend to exhibit greater similarity in economic cycles. Strongly synchronized cycles tend to show smaller variation in the economic product movements, as reported by Darvas and Szapáry (2008) and Czech Statistical Office (2004).

Visegrad group of central European countries (V4) was established in early 1991 during the meeting of the heads of states in Visegrad, Hungary. Primary goal of the new alliance was to establish platform for communication and cooperation between Poland, Hungary, the Czech Republic and Slovakia regarding transition of the former Soviet bloc states towards democracy and market economy with the ultimate goal to achieve NATO and EU membership. The V4 countries early proposed to ease the flow of goods, harmonize energy, cultural and defense policies and coordinate positions during membership negotiations with the EU. At present, V4 countries have the advantage of full EU participation and linger in the waiting room for Eurozone, except Slovakia, which opted to adopt Euro in 2009. It is currently the question of stringent compliance with the Maastricht criteria and increase of the public support for Euro in the V4 countries with own currency that remain to be tackled.

Objective of this study is to identify stages of the economic cycle in countries of the V4 group, Germany and Eurozone and assess synchronicity in the business cycles of the named economies. When two countries engage in intense foreign trade, their business cycles with time become correlated (Frankel and Rose, 1998). For this reason, it is hypothesized that accession of the V4 states to EU in May 2004 lead to abolition of trade barriers, upsurge in foreign trade and flow of capital among these countries and consequently raised likeness of respective business cycles. Therefore, in this paper, indicators of synchronicity were calculated independently for the periods before May 2004 and after. This allows direct comparisons of the correlation and similarity indicators for a specific pair of countries before EU entry and after and confirms or refutes the hypothesis that EU accession was the principal reason of business cycle synchronization among the new member states and among new and old EU member states. Additionally, synchronization is assessed with multiple indicators on country's economic cycle obtained by two unequal methods to reveal, whether they lead to the same conclusion. We postulate that synchronous economic cycles within EU is a necessary precondition for prospective flawless association of the newly accessed states in the Eurozone monetary union. It is especially the compliance of the candidate states with the principles of the Optimum Currency Area (OCA) formulated early by Mundell (1961) that reduce or even eliminate risks of asymmetric shocks and evoke adherence to the monetary policy of the ECB in the newly accessed economies. It is, on the other hand, the ever stronger integration of the product and financial markets that may favor more efficient capital allocation, increase specialization and thereby rise chance for occurrence of asymmetric shocks (Krugman, 1993; Czech Statistical Office, 2004). This is also known as the Krugman vs. the European Commission dispute.

\section{MATERIAL AND METHODS}

Data of quarterly GDP, calendar and season adjusted were obtained from the Statistical Database of Eurostat (2017) for the years 1995 to 2016. Countries covered were the Visegrad Group member states: the Czech Republic, Hungary, Poland and Slovakia, but also Germany and the Eurozone. Onset of the accessible Czech data was dated in 1996. In case of Poland, it was available much later starting in 2002. Data were expressed in millions of the local currency at the current prices, season and calendar adjusted. Simultaneously, we obtained the corresponding GDP deflator with the base year 2010. In case of Slovakia, the season-adjusted data were unavailable in the Eurostat database. Therefore we were forced to consider the available unadjusted data and subsequently performed the removal of the seasonal component by TRAMO-SEATS (Maravall and Caporello, 1996) with the assistance of the seasonal R-package (Sax, 2016). No other post download modifications of the data from the Euro area were carried out. Due to occurrence of non-stationarity in GDP time series, the data were further transformed to the natural logarithms of gross returns $\ln k_{t}=\ln y_{t}-\ln y_{t-1}$, where $k_{t}=y_{t} / y_{t-1}$ are the chain indices, $t=2,3, \ldots, T$. The stationary transformation has the advantage that provided $k_{t}$ distribution is log-normal, the distribution of the natural logs of $k_{t}$ turns out to be normal and the impact of the extreme observations and outliers on the overall variation thus becomes diminished. Pearson product moment correlation coefficient (1) was calculated to assess the strength and direction of the relationship between first-order differences (FODs) of the natural logs

$r_{x y}=\frac{s_{x y}}{\sqrt{s_{x}^{2} s_{y}^{2}}} \in\langle-1 ;+1\rangle$ 
Statistical significance of the regression coefficients was demonstrated with usual $t$-test (2)

$t=\frac{r_{x y} \sqrt{n-2}}{\sqrt{1-r_{x y}^{2}}} \sim t_{n-2}$

Historically, the methods of examining the business cycle were founded upon the principle that series of GDP estimates oscillate with time around general trend. Multiple smoothing procedures were therefore devised to isolate the cyclical movements in the economic product series from the overall central tendency, frequently nonlinear. The most notable are the BK band pass filter (Baxter and King, 1999), CF filter (Christiano and Fitzgerald, 2003) and the traditional HP filter (Hodrick and Prescott, 1997). These filters assume breakdown of the observed data into the nonlinear trend and cyclical movements around the trend following the equation (3)

$$
Y_{t}=\hat{Y}_{t}+C_{t}
$$

In the HP filter, the estimate of the trend component is received by minimizing the loss function (4)

$$
\sum_{t=1}^{T}\left(Y_{t}-\hat{Y}_{t}\right)^{2}+\lambda \sum_{t=2}^{T}\left\{\left(\hat{Y}_{t+1}-\hat{Y}_{t}\right)-\left(\hat{Y}_{t}-\hat{Y}_{t-1}\right)\right\}^{2}
$$

The optimality criterion implies minimizing the sum of squared cyclical deviations plus weighted sum of squared second-order differences of the trend. It is recommended for annual data that smoothing constant equals $\lambda=100$ (Hodrick and Prescott, 1997). In data with measurement frequency higher than one year, the proper constant is obtained via $\lambda=k^{2} \times 100$, where $k$ symbolizes measurement frequency of the actual data. In quarterly GDP data, we used $\lambda=1600$. Generally, higher lambda constant leads to smoother trend.

Insufficiencies of the HP filtering method concerning the smoothing quality in the periphery segments were reported by several authors. See, for example, papers by Hájek and Bezděk (2000), Harding (2002) or Kapounek (2009). In particular, it is stated that with HP estimation the potential product can be distorted and nonexistent cycle can be induced at both ends. Economic theory suggests, that the trend component represents the potential product, a level of GDP keeping the resources for economic growth in equilibrium state, and the residuals reflecting the output gap, technically the difference between the observed and the potential output. Positive value of the output gap is called inflationary gap, implying rise in price level, while negative value suggests recession gap, pointing to likely deflation. Estimated relative output gap can be yielded from the components of the HP filter breakdown by applying formula (5)
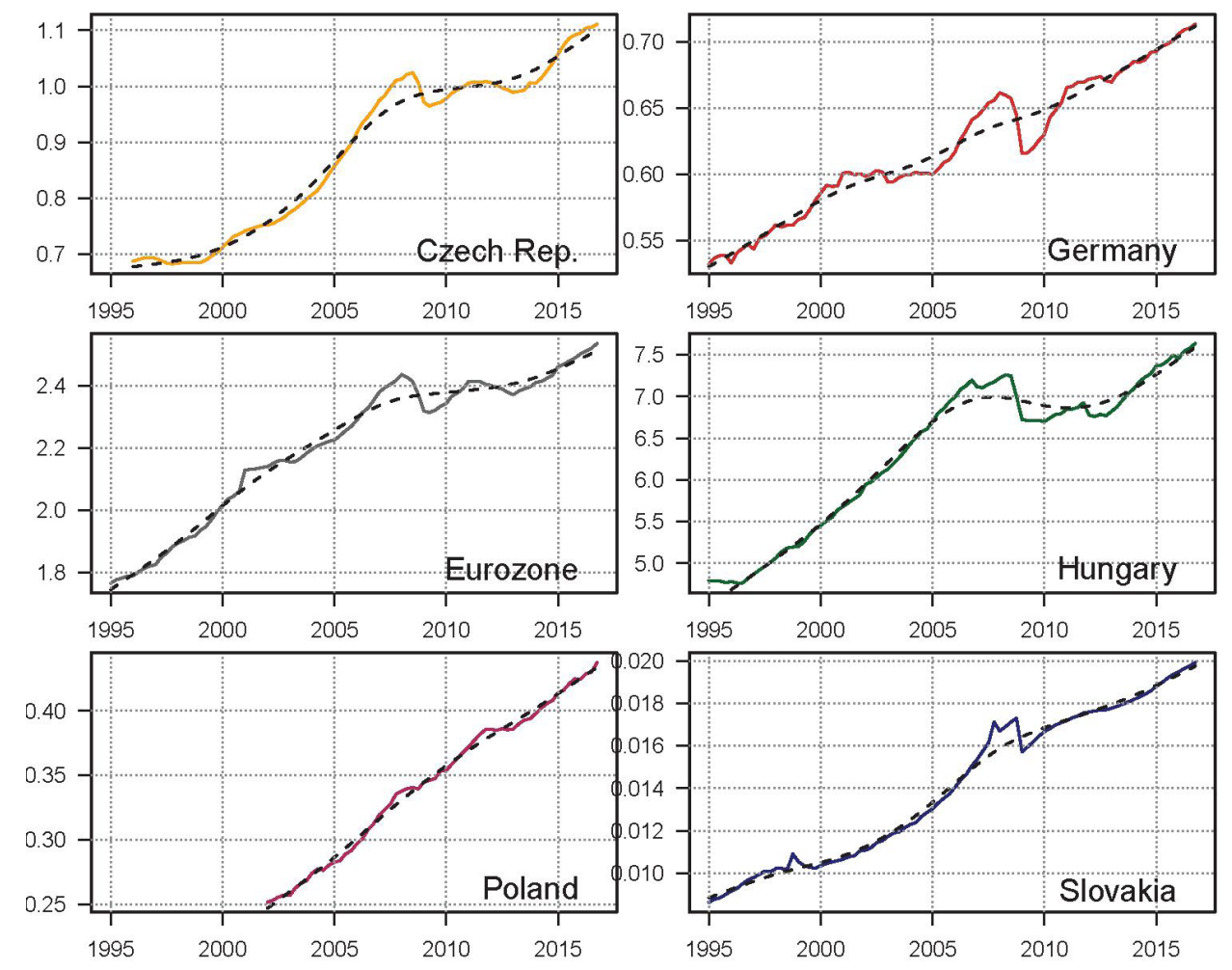

1: Quarterly GDP at 1000 bil. national currency of 2010, season and calendar adjusted during 1995-2016. HPtrend was marked with dashed line. 
$g_{t}=\frac{Y_{t}-\hat{Y}_{t}}{\hat{Y}_{t}} \times 100$

GDP data, calendar and season adjusted and the corresponding HP trend for the countries and areas under investigation are shown in Fig. 1. We applied R-software (www.r-project.org) extension package mFilter developed by Balcilar (2007) to carry out the data smoothing. Percentage change of adjusted quarterly GDP (year-to-year) is shown in Fig. 2.

Relative output gap is a valuable source of information for delineating phases of the economic cycle. This is done by applying the set of rules laid out by (Harding and Pagan, 2002 b) in form extended to quarterly data. BBQ algorithm was implemented in the computerized form in the add-on $R$ package BCDating by Einian (2014). It allows converting the $g_{t}$ variable to dichotomous form indicating the expansion (1) or recession (0) phases of the cycle, while respecting minimum length of 2 periods for a single phase and at least 5 periods per cycle. The BCDating library also calculates the average length of contraction and expansion phases of cycle (quarters) and mean amplitude of boom and bust (\%). Alternative procedure for defining business cycle phases was published by Canova (1998, 1999). Harding and Pagan (2002a) paper presents comparison of various dating procedures of the business cycle.

Statistical procedures to assess the extent of business cycle synchronization commonly include three fundamental indicators: Cramér coefficient of association $(V)$ or Pearson coefficient of correlation $r_{y x}$, coefficient of concordance and Mink coefficient of similarity $\gamma(t)$. Cramér $V$ is technically a coefficient of correlation between two binary variables indicating stages of the economic cycle: 1 =expansion and $0=$ recession in two countries or economic areas.
Significance of the $V$ coefficient can be tested by $t$-test, as shown in (2). Harding and Pagan (2006) proposed the synchronization index $I_{y x}$ as a relative proportion of concordant phases, i.e. 00 or 11 in two countries under assessment. The concordance index (6) can be easily obtained from the contingency table produced via cross tabulation. It stores simultaneous counts of concordant and discordant phases in both countries

$$
I_{y x}=\frac{n_{00}+n_{11}}{n_{00}+n_{01}+n_{10}+n_{11}} \in\langle 0 ; 1\rangle
$$

Under complete independence of the cycles, the realization of the concordance index is $I_{y x}=0.5$. If the cycles were positively correlated, $I_{y x}>0.5$ and with negative correlation $I_{y x}<0.5$. High strength of the relationship between cycles is indicated by value of the concordance index approaching zero or unity. For more information about relationship between the Pearson correlation coefficient and the concordance index, see Harding and Pagan (2006).

The index of economic cycle similarity (7) follows from the work of Mink et al. (2007). It measures similarity among indicators of the relative output gap $g_{t}$ in two countries: country $i$ to be compared and the reference country $r$, which is frequently the larger one in terms of the economic output (Kappel, 2015). Alternatively, Rozmahel and Najman (2010) proposed the reference variable be the average gap of both countries.

$\gamma(t)=1-\frac{\sum_{t=1}^{T}\left|g(i)_{t}-g(r)_{t}\right|}{\sum_{t=1}^{T}\left|g(i)_{t}\right|}$

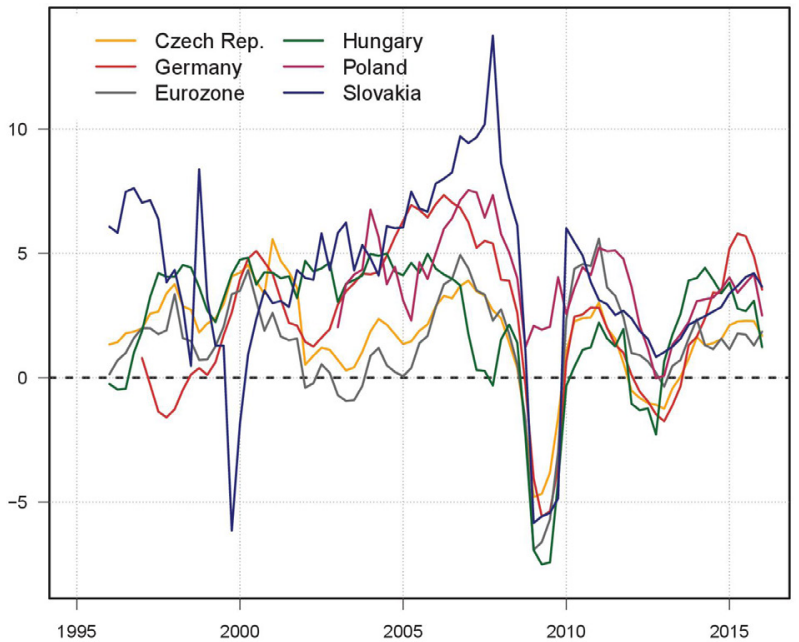

2: Quarterly GDP in mil. national currency, season and calendar adjusted during 1995-2016; year-on-year percentage change. 
Higher value of the Mink similarity index $\gamma(t)$ indicates tighter comparison between economic cycles (Kappel, 2015).

\section{RESULTS AND DISCUSSION}

Quarterly data of Gross Domestic Product in this exploration showed sizeable variation in mean and relative growth over the period covered. In general, the small and less advanced economies showed large absolute growth but also more instability in economic growth, when compared to the large and more advanced markets that on average grew slowly and showed only limited oscillations. Distributions of the GDP data were ostensibly skewed in all countries or economic areas. This discovery strongly justifies use of variance stabilizing transformations before statistical calculations. Descriptive characteristics for the season and calendar adjusted GDP in local currency and respective percentage changes are provided in Tab. I.

Differences in GDP growth can be noticed between the old and new EU member states. The new EU countries of V4 had on average faster relative growth, compared to Germany and Eurozone, where higher base was used and also where different local tax system was in place aiming at other priorities than attaining the fastest GDP growth (Tab. I). There is evidence in the economic growth data that V4 countries in general had more extreme peaks and deeper troughs in economic cycles relative to Germany and Eurozone, where the extremes appeared milder (see Tab. II or Fig. 2). This points to greater oscillation of the attained economic product relative to trend between the expansion and recession stages of the cycle in the Visegrad countries. This finding was especially evident in Slovakia and the Czech Republic. Due to unequal data size in the country series, we were unable to compare information about cycle counts among countries or areas during the period under examination. Percentage output gap (HP filter) and phases of the business cycle are presented in Fig. 3. Recessions were marked by color shading; regions with missing data in Poland and the Czech Republic were labeled by grey color.

The expansion phases were on average lasting longer than recessions in most countries with the exception of the Czech Republic, where on multiple occasions excessive restrictions in fiscal policy adopted by the country's governments during economic crises brought extra periods of recessions and contributed to delayed onset of economic recovery. Historically, the Czech Republic was at the forefront of the economic progress among the V4 states. As a result, the country's government relied more on convenient starting point for economic transformation together with geographical proximity to the target EU markets and subsequently postponed liberalizing some sectors of the economy, primarily privatization of the retail banks, deregulation of the housing sector, labor market and transforming health care. This was later reflected in slower economic growth, as compared to Slovakia or Poland that were initially in far inferior position in the 1990s and therefore became firmly motivated to undertake painful though necessary reforms.

In November 2013, the Czech National Bank commenced intervention in the foreign exchange market with the goal (among others...) to reduce the differential in inflation between the Czech economy and the Eurozone. As the Czech economy is small, open and substantial portion of the Czech foreign trade is realized with the Eurozone, the intervention did not slow down the mutual foreign trade nor the rate of business cycle synchronization of the Czech Republic and the Eurozone. Since 2000, the synchronicity of

I: Descriptive characteristics for the season and calendar adjusted GDP data expressed in local currency (upper) and year-to-year percentage change (lower) during 1995:1 to 2016:4.

\begin{tabular}{lccccccc}
\hline \multicolumn{1}{c}{ Country/Area } & Min. & $\mathbf{Q}_{0.25}$ & Median & Mean & SD & $\mathbf{Q}_{0.75}$ & Max. \\
\hline \multirow{2}{*}{ Czech Republic } & 682,714 & 744,400 & 940,158 & 884,933 & $142,758.8$ & $1,005,870$ & $1,110,873$ \\
& -5.59 & 0.56 & 2.57 & 2.41 & 2.93 & 4.68 & 7.34 \\
Germany & 532,120 & 590,929 & 613,265 & 621,022 & $50,954.9$ & 667,141 & 713,244 \\
& -6.92 & 0.54 & 1.57 & 1.37 & 2.16 & 2.38 & 5.59 \\
Eurozone & $1,766,652$ & $2,043,680$ & $2,279,286$ & $2,212,786$ & $226,088.1$ & $2,397,718$ & $2,535,795$ \\
& -4.80 & 1.05 & 1.87 & 1.68 & 1.88 & 2.76 & 5.56 \\
Hungary & $4,763,352$ & $5,539,954$ & $6,713,288$ & $6,339,850$ & 888,808 & $7,046,876$ & $7,637,663$ \\
& -7.51 & 1.22 & 3.14 & 2.24 & 2.72 & 4.15 & 4.99 \\
Poland & 251,845 & 291,058 & 346,978 & 344,624 & 56,005 & 387,137 & 437,331 \\
& -0.03 & 2.45 & 3.78 & 3.83 & 1.80 & 5.01 & 7.54 \\
Slovakia & 8,625 & 10,573 & 13,886 & 14,096 & $3,541.4$ & 17,345 & 19,932 \\
\hline
\end{tabular}


the Czech economic cycle with Eurozone was steadily increasing, as reported, for example, by Kappel (2015).

The economic position of Hungary was crippled by the local banking crisis that took place in the previous decade. At present, the country is completing its recovery from this misadventure.

Concerning the business cycle synchronization among V4 states and V4 and Germany or Eurozone, the estimated statistical indicators revealed valuable findings (see Tab. III and IV). It could be concluded, that before joining EU in May 2004, the economic cycles in V4 countries were mutually uncorrelated
(Tab. III) and only feeble relationships occurred with cycles of the EU15 states. The reader is advised that association coefficient of unity for Poland and Hungary was caused by shortage of available data and for this reason should not be overrated. Strong evidence of cycle synchronization in the period before 2004 was found between Hungary and Eurozone and Hungary and Germany, most probably due to intense across border trade of the countries with the EU partner. As expected, strong business cycle synchronization was evidenced for Germany and the Eurozone, as a result of strong and historically well-established economic

II: Mean characteristics for the phases of the economic cycle in countries (areas) under examination during 1995:1 to 2016:4.

\begin{tabular}{lccc}
\hline Country/Area & Phase & Mean duration & Mean amplitude \\
\hline \multirow{2}{*}{ Czech Republic } & Expansion & 9.5 & 4.5 \\
& Recession & 9.5 & 4.6 \\
\multirow{2}{*}{ Germany } & Expansion & 6.4 & 2.3 \\
& Recession & 4.3 & 2.4 \\
\multirow{2}{*}{ Eurozone } & Expansion & 7.0 & 2.7 \\
& Recession & 5.8 & 2.8 \\
\hline \multirow{2}{*}{ Hungary } & Expansion & 9.0 & 3.0 \\
\hline \multirow{2}{*}{ Poland } & Recession & 4.0 & 2.7 \\
& Expansion & 8.7 & 2.9 \\
\multirow{2}{*}{ Slovakia } & Recession & 5.7 & 3.0 \\
\hline
\end{tabular}
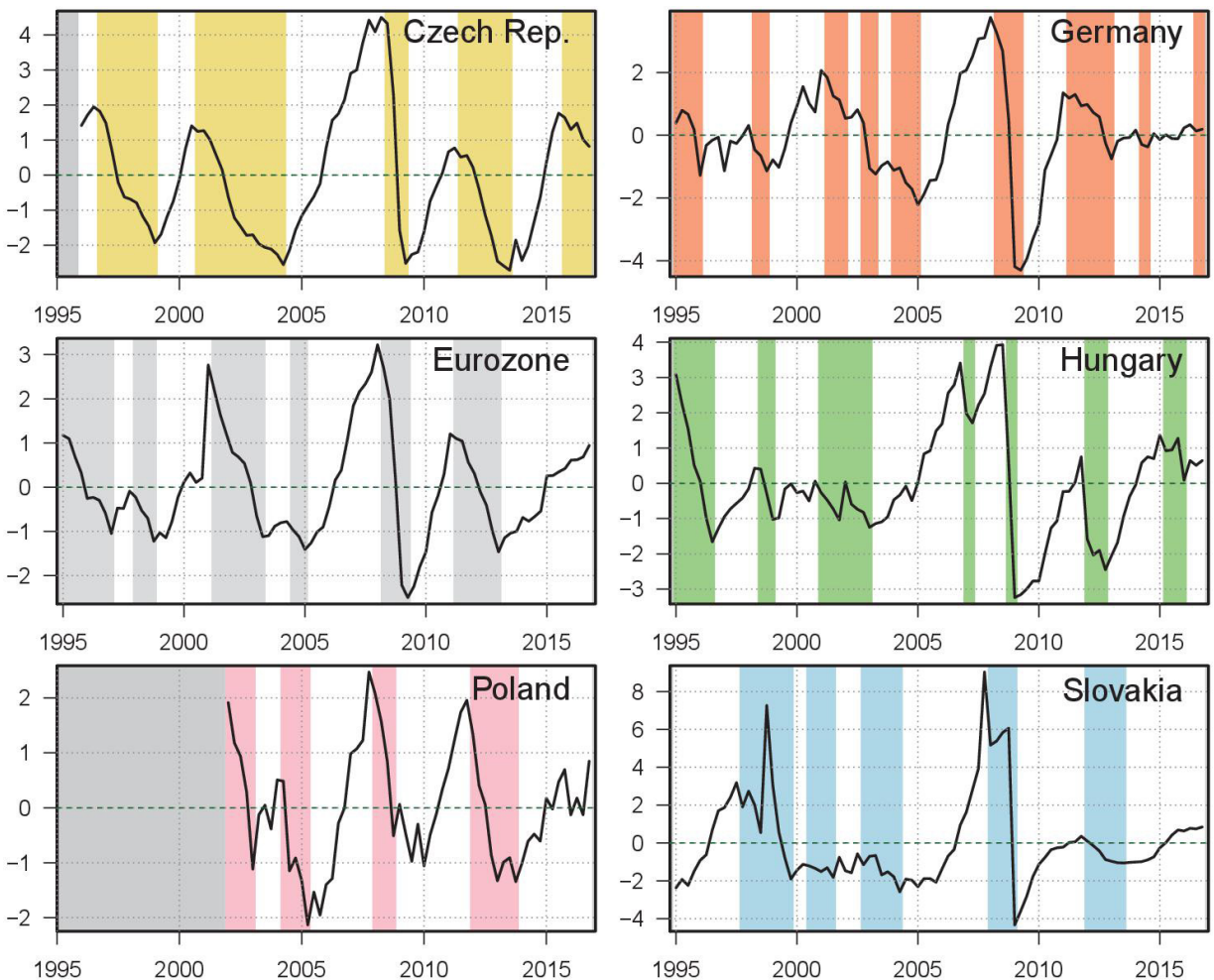

3: Relative output gap (HP filter) accompanied by phases of the business cycle. 
ties and strong weight of the German economy in the Eurozone. Nonetheless, business cycles of Slovakia or Hungary with some other countries were even negatively synchronized, i.e. counter-cyclical for the time segment before EU accession. During this period, these countries had only limited access to foreign markets, which impeded across border trade and contributed to low degree of economic ties or even negative correlations among the respective cycles. Lacina et al. (2007) reports that before 2004 cycles of the candidate countries were weakly correlated, while EU15 economies showed high degree of synchronicity, thus confirming strong structural and output similarity of the old EU states.

In the next period following EU accession (May 2004), the cycles of V4 countries and old EU member states became in most cases strongly and positively synchronized (see Tab. IV). The exceptions occurred mainly, where the mutual foreign trade between the two countries was hindered by large geographical distance or different structure of the economies, for example Poland and Hungary, Poland and Slovakia, Hungary and Germany or Poland and Germany, where growing Poland's internal market may have played role in this observation. In majority of country pairs, the size of the correlation coefficients between economic cycles or GDP growth could be explained by intensity of foreign trade between the respective economies: for example, the Czech Republic trades the most intensely with Germany, Slovakia and the Eurozone, but to lesser extent with Poland or Hungary. A similar observation was made for the Slovak economy with the key foreign markets the Czech Republic and Germany. Moreover, the similarity in economic cycles for Germany and the Eurozone shows over time strong and distinct upward tendency.

The above conclusion can be corroborated by reviewing the concordance indices calculated separately for the periods before EU enlargement and after (see Tabs. V. and VI.). For the period before EU enlargement in 2004, most indices were found to be around 0.5 or even lower, which signifies no correlation or even negative relationship. In the period after 2004, most coefficients became greater or even much greater than 0.5, which implies strong and positive correlation between the respective economic cycles. This endorses the premise that removal of trade barriers within EU facilitates intense foreign trade among member

III: Pairwise coefficients of correlation between phases of the business cycle (lower triangle) or simple log-differenced GDP (upper triangle) in the period before EU enlargement (2004:2). Two-tailed p-values are in parentheses.

\begin{tabular}{lcccccc}
\hline & CZ & DE & EZ & HU & PL & SK \\
\hline CZ & & 0.011 & 0.042 & 0.103 & 0.144 & -0.039 \\
& & $(0.952)$ & $(0.818)$ & $(0.574)$ & $(0.733)$ & $(0.829)$ \\
DE & 0.321 & & $\mathbf{0 . 7 5 7}$ & -0.096 & 0.478 & -0.175 \\
& $(0.068)$ & & $(0.000)$ & $(0.579)$ & $(0.231)$ & $(0.307)$ \\
EZ & 0.261 & $\mathbf{0 . 6 1 0}$ & & 0.059 & 0.331 & -0.259 \\
& $(0.143)$ & $(0.000)$ & & $(0.733)$ & $(0.423)$ & $(0.127)$ \\
HU & 0.149 & $\mathbf{0 . 5 2 2}$ & $\mathbf{0 . 6 2 8}$ & & 0.769 & -0.255 \\
& $(0.408)$ & $(0.001)$ & $(0.000)$ & & $(0.026)$ & $(0.134)$ \\
PL & & 0.1 & $\mathbf{0 . 7 9 1}$ & $\mathbf{1 . 0 0 0}$ & & -0.146 \\
& & $(0.798)$ & $(0.011)$ & $(0.000)$ & & $(0.730)$ \\
SK & 0.203 & 0.038 & -0.319 & -0.246 & -0.632 & $(0.068)$ \\
\hline
\end{tabular}

IV: Pairwise coefficients of correlation between phases of the business cycle (lower triangle) or simple log-differenced GDP (upper triangle) in the period after EU enlargement (2004:2). Two-tailed p-values are in parentheses.

\begin{tabular}{lcccccc}
\hline & $\mathbf{C Z}$ & $\mathbf{D E}$ & $\mathbf{E Z}$ & HU & PL & SK \\
\hline CZ & & $\mathbf{0 . 6 8 1}$ & $\mathbf{0 . 8 0 2}$ & $\mathbf{0 . 7 1 1}$ & $\mathbf{0 . 3 0 8}$ & $\mathbf{0 . 7 0 5}$ \\
& & $(0.000)$ & $(0.000)$ & $(0.000)$ & $(0.028)$ & $(0.000)$ \\
DE & $\mathbf{0 . 5 0 9}$ & & $\mathbf{0 . 8 7 7}$ & $\mathbf{0 . 6 6 9}$ & 0.213 & $\mathbf{0 . 6 4 3}$ \\
& $(0.000)$ & & $(0.000)$ & $(0.000)$ & $(0.133)$ & $(0.000)$ \\
EZ & $\mathbf{0 . 4 4 0}$ & $\mathbf{0 . 8 0 8}$ & & $\mathbf{0 . 7 0 4}$ & $\mathbf{0 . 4 2 5}$ & $\mathbf{0 . 5 7 0}$ \\
& $(0.001)$ & $(0.000)$ & & $(0.000)$ & $(0.002)$ & $(0.002)$ \\
HU & $\mathbf{0 . 3 3 7}$ & 0.099 & 0.223 & & 0.162 & $\mathbf{0 . 5 0 5}$ \\
& $(0.015)$ & $(0.487)$ & $(0.116)$ & & $(0.257)$ & $(0.000)$ \\
PL & $\mathbf{0 . 3 1 5}$ & $\mathbf{0 . 4 2 3}$ & $\mathbf{0 . 5 0 8}$ & 0.098 & & 0.147 \\
& $(0.024)$ & $(0.002)$ & $(0.000)$ & $(0.494)$ & & $(0.304)$ \\
SK & $\mathbf{0 . 5 7 3}$ & $\mathbf{0 . 4 2 5}$ & $\mathbf{0 . 4 7 7}$ & $\mathbf{0 . 3 1 2}$ & $\mathbf{0 . 7 3 2}$ & $(0.000)$ \\
\hline
\end{tabular}


V: Coefficients of concordance between phases of the business cycle (lower triangle) or coefficients of similarity (upper triangle) in the period before EU enlargement (2004:2).

\begin{tabular}{lcccccc}
\hline & CZ & DE & EZ & HU & PL & SK \\
\hline CZ & & $0.103^{R}$ & $0.101^{R}$ & $-0.972_{R}$ & $-0.215^{R}$ & $-0.167_{R}$ \\
DE & 0.576 & & $0.558^{R}$ & $-0.253_{R}$ & $0.000_{R}$ & $-0.261_{R}$ \\
EZ & 0.636 & 0.784 & & $-0.042_{R}$ & $-0.019_{R}$ & $-0.269_{R}$ \\
HU & 0.545 & 0.757 & 0.811 & & $-0.447^{R}$ & $-0.109_{R}$ \\
PL & 0.556 & 0.556 & 0.889 & 1.000 & & $-0.366_{R}$ \\
SK & 0.636 & 0.514 & 0.351 & 0.378 & 0.222 & \\
\hline
\end{tabular}

VI: Coefficients of concordance between phases of the business cycle (lower triangle) or coefficients of similarity (upper triangle) in the period after EU enlargement (2004:2).

\begin{tabular}{lcccccc}
\hline & CZ & DE & EZ & HU & PL & SK \\
\hline CZ & & $0.331^{R}$ & $0.520^{R}$ & $0.236_{R}$ & $0.211^{R}$ & $0.411_{R}$ \\
DE & 0.765 & & $0.508^{R}$ & $0.221_{R}$ & $-0.136_{R}$ & $0.419_{R}$ \\
EZ & 0.745 & 0.902 & & $0.302_{R}$ & $0.284_{R}$ & $0.481_{R}$ \\
HU & 0.706 & 0.588 & 0.686 & & $-0.025^{R}$ & $0.119_{R}$ \\
PL & 0.686 & 0.725 & 0.784 & 0.627 & & $0.281_{R}$ \\
SK & 0.804 & 0.725 & 0.784 & 0.745 & 0.882 & \\
\hline
\end{tabular}

states and over time contributes strongly to greater similarity in business cycles. Coefficients of similarity by Mink et al. (2007) are provided in the upper triangle of Tab. V for the period before EU accession and in Tab. VI for the period after joining EU. The reference country in the pair (R) was chosen to be the one with the larger economy and was marked either by the lower index for the row country or the upper index (column country). Although it should be noted that realizations of the Mink index depend tightly on the percentage output gap in the reference country, many pairwise similarity indices switched from near zero or negative in the segment before
May 2004 to clearly positive after May 2004. Observations for Poland for the period before EU accession nonetheless should be treated with restraint due to small sample size. All in all, this provides strong support for the fact that economies of the V4 member states are sufficiently synchronized and in this regard prepared for adoption of Euro in the foreseeable future. This of course excludes Slovakia, which already adopted Euro. Comparable observations of overtime increasing synchronization among cycles in EU countries, including V4 member states, based on segmented analyses were reported by Najman and Rozmahel (2013).

\section{CONCLUSIONS}

The question of economic cycle synchronization becomes very relevant, when candidate country prepares for joining monetary union to prove adherence to OCA criteria set forth by Mundell (1961). This is ultimately the case for the countries of the Visegrad group that declared their commitment to accepting Euro in accession treaties with the EU. In this paper, we identified phases of the economic cycle and assessed the degree of business cycle synchronization among V4 countries and also between V4 and their major business partners Germany and Eurozone via pairwise correlation analysis and indices of concordance and similarity. Contrary to some historical studies (see, for example Rozmahel and Najman, 2010; Rozmahel, 2011; Kappel, 2015), the current exploration of business cycles was done separately for the periods before joining EU in 2004 and after to visualize the influence of onset of EU membership upon the degree of business cycle synchronization. It found stable proof that before the extensive EU enlargement in May 2004, few economic cycles were synchronized just weakly, but many were not synchronized or were counter cyclical. Only the business cycles of Germany and Eurozone displayed apparent and anticipated positive correlation and synchronization (Darvas and Szapáry, 2008; Czech Statistical Office, 2004). Though we are aware that Germany's economic output appeared in both correlated variables and likely inflated the indicators of correlation or synchronization. This circumstance, however, did not compromise relevance of the current analyses and conclusions drawn therefrom, due to indirect impact of the German economy on the Eurozone. In the later period after 2004, the economic cycles became strongly synchronized among V4 countries or between V4 member state and Germany or Eurozone, as evidenced in all statistical 
indicators of synchronization. The only exception was Hungary, where prolonged economic havoc caused lower degree of similarity in economic growth with many other EU countries. Admittedly, this study was unable to adequately demonstrate the degree of cycle synchronization or the absence of it for country pairs, which include Poland due to small sample size in the period before 2004. Results in the later period, however, remain unaffected. Further, this study was not aimed at quantifying structural contributions to cycle (counter)synchronization between country pairs and this task still remains to be tackled. Presently, it is predominantly the low across border mobility of the labour that is contributing to divergence in economic cycles among the EU economies, especially in the recession phase of the cycle (Czech Statistical Office, 2004). Improvements in the inflexible labour markets was proposed by Lacina et al. (2007) as an effective mechanism to help countries cope with asymmetric shocks.

The current findings nevertheless do support the hypothesis formed by Frankel and Rose (1998) that absence of barriers for across border trade causes increasing likeness in economic development and over time makes business cycles of the participating countries more synchronized. Although the degree of synchronization between V4 economies and the Eurozone is not currently as strong, as for Germany and Eurozone, it is recognized that countries of the V4 group are sufficiently apt in this regard for considering Euro, as their national currency. In 1992, the EU approved so called Maastricht criteria, as a precondition for adopting Euro. It is therefore up to the candidate states to work conscientiously towards establishing steady place in the Eurozone club.

Acknowledgements

The author acknowledges assistance Vendula Konvalinová, Michaela Krejčová and Marie Blahová provided during their internship.

\section{REFERENCES}

BALCILAR, M. 2007. mFilter: Miscellaneous Time Series Filters. R package version 0.1-3. Available at: https:// CRAN.R-project.org/package=mFilter [Accessed: 2017, August 8].

BAXTER, M. and KING, R. G. 1999. Measuring Business Cycles: Approximate Band-Pass Filters for Economic Time Series. The Review of Economics and Statistics, 4(81): 575-593.

CANOVA, F. 1998. Detrending and Business Cycle Facts. Journal of Monetary Economics, 41(3): 533-540.

CANOVA, F. 1999: Does Detrending Matter for the Determination of the Reference Cycle and the Selection of Turning points? The Economic Journal, 109(452): 126-150.

CHRISTIANO, L. J. and FITZGERALD, T. J. 2003. The Band Pass Filter. International Economic Review, 44(2): 435-465.

CZECH STATISTICAL OFFICE, 2004. Procesy synchronizace vývoje hospodárského cyklu v EU. Internal document of the Czech Statistical Office. Available at: https://www.czso.cz/ documents/10180/20537824/15160406. pdf/a46d8f96-2764-4483-847b-13c99cf5c57b? version =1.0 [Accessed: 2017, October 5].

DARVAS, Z. and SZAPÁRY, G. 2008. Business Cycle Synchronization in the Enlarged EU. Open Economies Review, 19(1): 1-19.

DORNBUSCH, R., FISCHER, S. and STARTZ, R. 2011. Macroeconomics. $11^{\text {th }}$ edition. New York: McGraw-Hill.

EINIAN, M. 2014. BCDating: Business Cycle Dating and Plotting Tools. R package version 0.9.7. Available at: https://CRAN.R-project.org/package=BCDating [Accessed: 2017, August 8].

EUROSTAT. 2017. Statistics Database. [Online]. Available at: http://epp.eurostat.ec.europa.eu/portal/page/ portal/statistics/search_database [Accessed: 2017, August 8].

FRANKEL, J. A. and ROSE, A. K. 1998. The Endogeneity of the Optimum Currency Area Criteria. The Economic Journal, 108(7): 1009-1025.

HÁJEK, M. and BEZDĚK, V. 2000. Odhad potenciálního produktu a produkční mezery v ČR. Working paper No. 26. Praha: Česka národní banka.

HARDING, D. 2002. The Australian Business Cycle: A New View. MPRA archive. Available at: http://mpra. ub.unimuenchen.de [Accessed: 2017, August 8].

HARDING, D. and PAGAN, A. 2002a. A Comparison of Two Business Cycle Dating Methods. Journal of Economic Dynamics and Control, 27(9): 1681-1690.

HARDING, D. and PAGAN, A. 2002b. Dissecting the Cycle: a Methodological Investigation. Journal of Monetary Economics, 49(2): 365-381.

HARDING, D. and PAGAN, A. 2006. Synchronization of Cycles. Journal of Econometrics, 132(1): 59-79.

HODRICK, R. and PRESCOTT, E. C. 1997. Postwar U.S. Business Cycles: An Empirical Investigation. Journal of Money, Credit, and Banking, 29(1): 1-16.

KAPOUNEK, S. 2009. Estimation of the Business Cycles - Selected Methodological Problems of the Hodrick-Prescott Filter Application. Polish Journal of Environmental Studies, 18(5B): 227-231.

KAPPEL, S. 2015. A Comparison of Business Cycles Synchronization in the Euro Area and Some Potential Monetary Unions. Acta Univ. Agric. Silvic. Mendelianae Brun., 63(4): 1277-1285. 
KRUGMAN, P. 2013. Lessons of Massachusetts for EMU. In: Torres, F. and Giavazzi, F.: Adjustment and Growth in the European Monetary Union. Cambridge University Press and CERP, p. 241-261.

LACINA, L. et al. 2007. Ménová integrace: náklady a prínosy členství v ménové unii. Praha: C. H. Beck.

MARAVALL, A., GÓMEZ, V. and CAPORELLO, G. 1996. Statistical and Econometrics Software: TRAMO and SEATS. Madrid: Banco de España.

MINK, M., JACOBS, J. and DE HAAN, J. 2007. Measuring Synchronicity and Co-movement of Business Cycles with an Application on the Euro Area. CESifo Working Paper Series No. 2112. Munich: CESifo Group.

MUNDELL, R. A. 1961. Theory of Optimum Currency Areas. American Economic Review, 51(4): 657-665.

NAJMAN, N. and ROZMAHEL, P. 2013. Business Cycle Coherence and OCA Endogeneity Testing During the Integration Period in the European Union. Acta Univ. Agric. Silvic. Mendelianae Brun., 61(4): 1033-1040.

R DEVELOPMENT CORE TEAM. 2017. R: A Language and Environment for Statistical Computing. Vienna, Austria: R Foundation for Statistical Computing. Avaialable at: www.r-project.org

ROZMAHEL, P. 2011. Measuring the Business Cycle Similarity and Convergence Trends in the Central and Eastern European Countries towards the Eurozone with Respect to Some Unclear Methodological Aspects. Acta Univ. Agric. Silvic. Mendelianae Brun., 59(2): 237-250.

ROZMAHEL, P. and NAJMAN, N. 2010. Index shody hospodářského cyklu České republiky a vybraných zemi střední a východní Evropy s Eurozónou. Acta Univ. Agric. Silvic. Mendelianae Brun., 58(6): 407-414.

SAX, C. 2016. seasonal: R Interface to X-13-ARIMA-SEATS. R package version 1.3.0. Available at: https://cran.rproject.org/package=seasonal [Accessed: 2017, August 15]. 